\title{
Gerald Grace and the philosophy of Catholic education
}

\author{
Sean Whittle
}

\section{Introduction}

This chapter will tease out Gerald Grace's relationship with the philosophy of Catholic education. ${ }^{1}$ At the outset, it is essential to note that Grace would be the first to point out that he is firmly an historian and a sociologist of education and he would delineate a sharp distinction between these disciplines and that of the philosophy of education. Respecting his firm distinction, this chapter will present its analysis in three stages. First, it will demonstrate that Grace has repeatedly drawn attention to there being a contemporary need for a clear articulation of the philosophy of Catholic education. Second, praise will be given to the way that Grace has skilfully used his role as editor of the journal International Studies in Catholic Education (ISCE) to foster and promote fresh debate and clarification around the philosophy of Catholic education. A brief overview of this debate will be presented. The third stage of the analysis will focus on identifying what would amount to Grace's stance on the philosophy of Catholic education. It will be explained that for Grace this philosophy is built around the imperative of serving the educational needs of the poor. This is, of course, somewhat different to the typical approach, defended in Church teachings, which has traditionally built the philosophy of Catholic education around parental rights. By way of conclusion, the analysis will briefly take up Grace's stance on the philosophy of Catholic education and point out the potentially far-reaching impact it could have on Catholic schooling and educational policy. It will be proposed that, perhaps, Gerald Grace could be regarded as being prophetic in his convictions about how the Church in the modern world ought to be framing its philosophy of Catholic education around the option for the poor.

\section{On the contemporary need for a philosophy of Catholic education}

Grace's seminal work, Catholic Schools: Mission, Markets and Morality (2002), draws attention to the paucity of contemporary work on the philosophy of Catholic education. This book presents ground-breaking empirical research

DOI: $10.4324 / 9781003171553-12$ 
about the nature and effectiveness of Catholic schooling in secular Britain. Grace found the relative underdevelopment of a philosophy of Catholic education 'surprising' and that a suitable defence of it might have been expected, one 'constructed by Catholic philosophers' (2002, p. 16). He concurred with others (notably Carr et al 1995) that new efforts are needed to produce a contemporary philosophy of Catholic education. In calling attention to this situation, Grace was not alone. Others, such as Elias (1999), had pondered over the decline of formal Catholic philosophies of education. Elias mused on the number of works in the middle of the twentieth century that had deployed Neo-Thomism to frame, justify and conceptualise Catholic education, yet none of these had been updated or had remained in favour after Vatican II. In a roughly similar vein, Kelty (1999) describes how following Vatican II the attention shifted away from formulations of the philosophy of education to the theology of Catholic education.

According to Grace, in the absence of a fully articulated philosophical framework, advocates of Catholic education have used the various publications from the Congregation for Catholic Education as a source of guiding principles. He points out that

In so far as contemporary Catholic schooling, in England at any rate, can claim to be an articulated theoretical framework, it has been derived from these "documents for guidance" rather than from the developed insights of formal scholarship.

(2002, p. 17)

This careful and measured assessment indicates that Grace shares the concerns raised by McLaughlin (1996), who drew attention to the tendency to use phrases such as Gospel values or statements from the various education guidance documents to act as a proxy for a properly developed philosophy or theory of Catholic education. The problem with them is two-fold. First, such theological slogans give the false impression that there is a clearly worked-out account of what they actually involve or refer to. Second, they have stifled the task of developing a robust theory of Catholic education because they are repeatedly not recognised for what they actually are. As McLaughlin observes, 'such phrases are primarily useful as spurs to a deeper discussion, not a substitute for it' (1996, p. 138). Far too often these, theologically inspired, slogans or expressions of piety are treated as if they summarise all that needs to be said to frame and justify Catholic education. According to McLaughlin, too often the education documents are 'mined' for such phrases in a rather eclectic way (p. 138). ${ }^{2}$

Thus, in order to justify and frame Catholic education, Grace had little option but to focus on the insights of two key education documents. The first is Vatican II's Declaration on the Extreme Importance of Christian Education (Gravissimum Educationis, 1965). This relatively short statement is part-and-parcel of the aggiornamento or updating of the second Vatican Council (1962-65), when the 
leaders of the Catholic Church sought to engage with what it means to be the Church in the modern world. According to Grace:

The declaration, Gravissimum Educationis (1965), was therefore calling for a new mode of Catholic schooling to meet the challenges of a modern and secular culture and the needs and expectations of young people growing to maturity in such a culture.

(2002 p. 18)

In addition, the declaration calls attention to members of the Church enabling Catholic schools to become better in 'Caring for the poor, for those who are without the help and affection of family and those who do not have the faith' (Gravissimum Educationis par. 9). This sentence reflected a recalibration of the mission of the Catholic school, reaffirming a tradition of attending to the poor and responding to those who face family breakdown, but also introducing a recognition about the mixed nature of the contemporary Catholic school. The bishops at Vatican II were aware that in many parts of the world, Catholic schools are not primarily full of Catholic children. Formally recognising this, even in this fleeting manner, was a significant point of departure for reframing and challenging assumptions about who and what the Catholic school is for. This tacit modification of the philosophy of Catholic education is part of how Vatican II achieved some aggiornamento in relation to Catholic education.

The second education document was issued twelve years after the close of the Council. It was promulgated as a guidance document issued by the Vatican's Congregation for Catholic Education and it had the title The Catholic School (1977). According to Grace, it is this document which

...reasserted the role of education as part of the saving mission of the Church to reveal to all ages the transcendent goal which alone gives life its full meaning (p. 13). The influence of Catholic social teaching is particularly evident in this document where the principle of special concern for the deprived in education and again it is emphasised: "First and foremost the Church offers its educational service to the poor" (The Catholic School, 1977 par. 58).

(Grace, 2002, p. 19)

For Grace, more so than Gravissimum Educationis, this document gives an emphatic focus on Catholic education being primarily a service to the common good of society and firmly directed at serving the poor. ${ }^{3}$ This document had the benefit of being composed in the first flush of Vatican II's reception. ${ }^{4}$ There was already, just twelve years after the final session of Vatican II, a growing sense of the Church's 'option for the poor' and the realisation that its priority is not in supporting the status quo but in clearly being on the side of the poor. The 1977 document applied this insight to Catholic education. For Grace, this emphatic 
alignment between the Catholic school and serving the poor gives the 1977 guidance an importance that supersedes the Council's declaration. This means that the educational mission of the Catholic school can be summed up as serving the poor. For Grace, this pithy summary of the philosophy of Catholic education was able to serve as the starting point for his empirical research into the situation facing headteachers leading Catholic schools in England.

In Catholic Schools: Mission, Markets and Morality (2002), Grace reported the finding of his field work in sixty inner-city schools. He draws out the extremely difficult situation which Catholic education in England finds itself in because of explicit government policies to create a market place within educational provision. Grace described the tortuous situation that Catholic headteachers find themselves in because of the huge changes in government-led educational policies over a twenty-year period. There is quite literally a deep tension between the mission of Catholic schools and the educational market place that they have been forced to operate within. As Grace explains:

If schools in a market economy in education must show good company results in academic success and growing social status, what becomes of the Catholic school principle of 'preferential option for the poor'?

(Grace, 2002, p. 181)

In order to survive there have had to be compromises and accommodations. Grace is maintaining that Catholic education has had to adapt to making academic achievement and league table position an ever-increasing priority. Given this, Catholic schools are being deflected from their primary mission. Grace's 2002 work is a rallying cry to take urgent action to ensure that there will be sufficient Spiritual Capital ${ }^{5}$ to allow future Catholic school leaders to maintain the core mission of Catholic education, particularly in the face of market values dominating education. A key part of the action needed is the development of a fully worked-out philosophical framework, to underpin the successful transmission of Spiritual Capital.

\section{Gerald Grace's role in promoting debate about the philosophy of Catholic education}

Having drawn attention in 2002 to the urgent need for a contemporary robust and developed philosophy or theory of Catholic education, Grace was able to play a role in fostering debate around it. This came about from 2009 onwards, as a direct result of his work as the editor of ISCE. As the founding editor of this international journal, Grace has been able to kick-start a dialogue about a contemporary philosophy of Catholic education. It was in volume 3 of ISCE that he presented the first article that dealt specifically with the contemporary philosophy of Catholic education, written by Professor Brendan Carmody (2011). Grace's firm hope was that 'this contribution will stimulate a debate 
and further articles on this crucial subject' (2011, p. 2). His astute observation was correct, because it resulted in, to date, three other contributions that have sought to take further this formal philosophical reflection over the aims and justification of Catholic education.

There is richness to the debate and dialogue that Grace's editorship of ISCE has gifted to the field of Catholic Education Studies that deserves to be briefly summarised here. In Carmody's original article (2011), the argument is built around the proposal that the Jesuit philosopher Bernard Lonergan's account of self-transcendence could provide the framework for a contemporary philosophy of education. The mission of Catholic education is to foster a religious conversion through schools that are inclusive but are also 'distinctive, where faith, reason and life are brought into an integrated relationship as a holistic education experience' (Carmody, 2011, p. 113). Given this, the mission of Catholic education can be characterised as being concerned with ensuring or promoting a real assent among students. This could be taken as a partial response to those who would be critical of the place of religion (or theology) in the curriculum. Carmody skilfully indicates how general themes in Lonergan's philosophy could be used to inform or frame Catholic education. This involves a commitment to social justice and to dialogue with all others, including those who belong to different religions. Catholic education sets out to be open to other faiths and is able to challenge the materialism and self-centred attitudes that can dominate contemporary life. In response to Carmody's position, I offered an alternative way of framing the philosophy of Catholic education around insights from another leading Jesuit scholar, the theologian Karl Rahner. This contribution (Whittle 2014a) describes how at the heart of Rahner's theology is an insistence about the significance of mystery in human life, and it is this theological insight which can be used to inspire and stimulate a range of educational arguments that provide the basis for a contemporary theory or philosophy of education. When developed with reference to Rahner's method, Whittle is even able to provide a theological justification for a non-confessional account of Catholic education. ${ }^{6}$ As part of this, it can be argued that the curriculum as a whole has a central role to play in bringing pupils to what Rahner described as the threshold of theology. It is the whole curriculum, rather than just Religious Education, that has a role to play in ensuring that pupils recognise the mystery within human existence.

In 2018, two further contributions to the debate appeared in ISCE. The first, by Mario D'Souza, sought to offer further reflections on the philosophy of Catholic education through a critical scrutiny of the contributions from Carmody and Whittle. Although he could see merits in both, his analysis leads on to a detailed argument that favours the relevance of both Lonergan and the neo-Thomist philosopher Maritain, for framing and justifying Catholic education. In the second part of volume 10 (2018), an important contribution from Paddy Walsh appeared that returned to an analysis of how both Lonergan and Rahner are able to reconfigure the contemporary philosophy of Catholic education. Walsh skilfully sought to demonstrate that there is a significant level of complementarity in what these 
truly great thinkers can together offer as a philosophy of Catholic education fit for our times. In particular, he wanted to combat a tendency in Whittle's contribution to the debate, which championed Rahner over Lonergan. Walsh neatly encapsulates the movement away from drawing a sharp distinction between the 'philosophy' as opposed to the 'theology' of Catholic education. Spelling this out in the detailed way that Walsh does amounts to an important contribution to the contemporary philosophy of Catholic education. Theology and philosophy are inextricably interwoven within the philosophy of Catholic education, particularly in the light of Vatican II's aggiornamento.

Nestled alongside these more formal contributions, Grace's editorship of the journal ISCE has, over the past twelve years, sought out further opportunities to put the spotlight on the philosophy of Catholic education. For example, in the inclusion of works in the book review section, the editor of ISCE has always opted to offer readers detailed and high-quality book reviews, which feature very few works - typically just two or three per edition. Crucially, books about the philosophy of Catholic education have been included in this highly select review of works in the field of Catholic Education Studies. For example, Professor Richard Pring's philosophical analysis, The Future of Publicly Funded Schools (2017), was afforded two reviews in the same edition (ISCE 2019, issue 1). Similarly, one of the only book-length monographs from the past decade dealing with the theory or philosophy of Catholic education was given a lengthy review by Dylis Wadman (2015). ${ }^{7}$ Moreover, other contributors such as Carmody (2017) have explored issues which are central to philosophical debates within the philosophy of Catholic education. In this article, Carmody critiques the very idea of there being a non-confessional Catholic education and takes issue with using Rahner to avoid the spectre of indoctrination from Catholic education.

In all this, Grace as editor of ISCE has performed an important service in nurturing debate and dialogue surrounding the contemporary philosophy of education. In October 2020 (ISCE 2020, p. 129), it was announced that Grace would be relinquishing his editorial role at the end of 2021. It is vital that the same level of attention will be given to fostering and nurturing the much-needed contemporary philosophy of education within the pages of ISCE under new editor(s). Having begun this commendable work, it will be incumbent on others to build on what Grace has achieved in this aspect of Catholic education scholarship.

\section{Grace's stance on the philosophy of Catholic education: An assessment}

Having described how Grace has made both a strong case for the contemporary need for a philosophy of Catholic education and then outlining the steps he has taken to promote it, attention can now shift to teasing out Grace's own take on what it involves. This is to return to the observation made above, about the way in which Grace embraced the alignment between the Catholic school and serving the poor in the 1977 document on The Catholic School. 
In latching upon paragraph 58 , which includes the sentence that emphatically declares 'first and foremost' the Church is making its educational provision available to the poor, Grace has identified an embryonic philosophy of Catholic education. It is one that characterises the Church's education work as something which is depicted as both an offer and a service to those who are poor, deprived of family help and affection and those who are far from the Catholic Christian faith. In being an offer, Catholic education is not being framed in terms of the rights of the Church or as something that could be imposed on others. As an offer, it has the quality of being 'gift-like' and like all genuine offers it comes without any strings or conditions attached. In addition, in being a service, Catholic education is something openly or freely available to those who are in need of it. In that sense, it is not a commodity which can be traded or bought. This is a point emphasised in paragraph 58, when it lists those for whom a Catholic education is intentionally and primarily seeking to serve - those who are poor or are in significant need. These are the marginalised or underclass of society and as such, they are the least able to pay and stand in most need of the offer and service afforded in a Catholic education. Another facet of this embryonic philosophy of Catholic education is the clause of the sentence which declares that the offer and service is specifically extended to those who are 'far from the faith'. This means a Catholic education is not, first and foremost, something that is exclusively for the children of Catholic parents. Thus, it is possible to draw out from this embryo the central elements of a highly inclusive and socially just philosophy of Catholic education.

This conclusion is powerfully reinforced when paragraph 58 of The Catholic School is read as a whole, rather than just the sentence that Grace hones in on.

Since it is motivated by the Christian ideal, the Catholic school is particularly sensitive to the call from every part of the world for a more just society, and it tries to make its own contribution towards it. It does not stop at the courageous teaching of the demands of justice even in the face of local opposition, but tries to put these demands into practice in its own community in the daily life of the school. In some countries, because of local laws and economic conditions, the Catholic school runs the risk of giving counter-witness by admitting a majority of children from wealthier families. Schools may have done this because of their need to be financially self-supporting. This situation is of great concern to those responsible for Catholic education, because first and foremost the Church offers its educational service to "the poor or those who are deprived of family help and affection or those who are far from the faith". Since education is an important means of improving the social and economic condition of the individual and of peoples, if the Catholic school were to turn its attention exclusively or predominantly to those from the wealthier social classes, it could be contributing towards maintaining their privileged position, and could thereby continue to favour a society which is unjust.

(The Catholic School, 1977, par. 58, emphasis added) 
There is a strong sociological analysis built into this paragraph. It begins from a global awareness for the need for social justice, which needs to be built into both what is taught and lived out in the daily practice of the Catholic school. Whilst the text recognises the need for Catholic schools to be financially viable, there is a real danger they could actually give a counter-witness by favouring children from wealthier families. In fact, the paragraph hinges on sociological arguments about education being a powerful engine of social improvement and a way of bringing about social justice. Thus, Catholic education has an important role to play in transforming socio-political relationships within societies across the world. The Church has to ensure its educational provision and service are put to work improving social justice throughout society, rather than (inadvertently) maintaining the power or privilege of the wealthy in society. This is a philosophy of Catholic education that puts the pursuit of social justice at the centre stage of its work. With this level of sociological analysis, it is hardly surprising that Grace, given his grounding in the sociology of education and his practical commitment to inclusive and socially just education practices, would have been drawn to the significance of paragraph 58 .

However, it is important to acknowledge that Grace's recognition of this embryonic philosophy of Catholic education is a significant break from the typical ways of justifying and framing Catholic education. For almost a century, the standard way to justify and frame Catholic education was through the lens of 'parental rights', following the pattern of arguments presented in Pius XI's encyclical of 1929. To date, this is the only papal encyclical about Catholic education and as such it stands out as an important statement of official Church teaching on Catholic education. This encyclical, known under its Latin name of Divini Illus Magistri, is about the Christian education of young people. The encyclical reaffirms the right of the Catholic Church to be involved in education and schooling. To do this, Divini Illus Magistri employed a rights-based argument that employed the scaffolding provided by Natural Law principles. ${ }^{8}$ It assigned three levels to socio-political relationships. ${ }^{9}$ The encyclical maintained that whilst the family comes first, it is dependent on the wider civil society if it is to achieve its purpose. One of the important roles of civil society is to support families in various ways, including educational provision and ensuring that the rights of families are met. The encyclical also maintained the prerogative of families to exercise their legal rights to bring up their children in their religion. The encyclical argued that, as a consequence, the Catholic Church has both a right and a responsibility (towards families) to be involved in the provision of State education. The encyclical argued that the State must recognise the rights of the Church in this area and that it ought to be contributing financially to support Catholic schools.

Gravissimum Educationis deliberately sought to reaffirm much of what Pius XI had stated in 1929. However, notably, this Vatican II declaration recast the language and tone of the encyclical in the way it explained the Church's 
ongoing commitment to Catholic education and schooling. Crucially, it affirmed the importance of parental rights to justify Catholic education and the political right of the Church to be involved in State education. This rights-based argument (built on the rights of parents as the primary educators) for Catholic education is also enshrined in Canon Law and as such, it has endured as the typical or default way of summing up the philosophy of Catholic education. However, this is significantly different to the position outlined in paragraph 58 of The Catholic School, which just does not utilise the concept of parental rights. It might well be that there is a way of synthesising these competing approaches to underpin the philosophy of Catholic education; however, this has not yet been identified. Grace, and those who are persuaded by his arguments around the importance of The Catholic School guidance document, is eschewing the typical approach, defended in key Church teachings, which builds the philosophy of Catholic education around parental rights alone. ${ }^{10}$

\section{Concluding observations}

By way of conclusion, it is interesting to speculate, albeit briefly, on what the potential impact might be if Grace's stance on the philosophy of Catholic was to be widely taken up and put into practice, particularly in the UK. ${ }^{11}$ First, there would be a significant readjustment of admission policies for those seeking a place in Catholic schools. Typically, in English Catholic schools, baptised Catholic children are prioritised for admission. However, Grace's philosophy of Catholic education would mean also prioritising poor and socially disadvantaged students. ${ }^{12}$ It is important to reiterate that it is for all who are poor and needy, rather than just poverty-struck or disadvantaged Catholic children. Almost inevitably this would lead to a further decline in the proportion of Catholic children in English Catholic schools. ${ }^{13}$

In addition, those who are 'far from the faith' need to be able to find a welcome in Catholic schools. This firm inclusion of those who are 'far from the faith' has some wide-ranging implications for the intentions and goals of a Catholic education. For example, no longer can the fostering or reinforcement of Catholic identity be a central goal. Trying to inculcate a Catholic identity in those children who are 'far from the Catholic faith' would sound alarm bells about the risk of indoctrination, or just the simple failure to welcome these students without wanting to convert them. Thus, Grace's stance allows us to envision a highly inclusive Catholic school, in which there may well be only a minority of students from Catholic families, and because it welcomes those who are far from the faith, it does not impose the Catholic faith on its students. Presumably this would call for a reconfiguration of Religious Education in Catholic schools, moving away from overtly Catholic content and embracing the need to teach a range of worldviews. This sounds very much like the non-confessional account of Catholic education that others have argued in favour of (such as Whittle, 2014a, 2014b). ${ }^{14}$ 
When it comes to specific education policies, the stance Grace adopts towards the philosophy of Catholic education challenges educational policy in a number of ways. At the obvious level, it would seriously challenge the existence of private or fee-paying Catholic schools, which in the UK are known as independent schools. Given that education is a service to society, it ought not to be reduced to a commodity which can be purchased by the wealthier members of society. As such, it becomes incredibly difficult to justify the existence of Catholic independent schools. At the less obvious level, another but perhaps far more wide-reaching educational policy that is called into question is the drive towards 'academisation', in which schools in England can be directly funded by the Department for Education. ${ }^{15}$ The Academy agenda has been highly disruptive, in particular allowing 'market forces' and competition between schools to increase way beyond those worrying levels which Grace first described over two decades ago in Catholic Schools: Mission, Markets and Morality (2002). A situation where Catholic academies are in open competition with other Catholic schools goes directly against the primary mission of serving those who are most in need of a Catholic education. Perhaps the only way of justifying the academisation of Catholic schools would be through a radical reconfiguration of Catholic academies into schools that are exclusively for poor and socially disadvantaged students. Thus, an educational landscape where Catholic independent schools have a changed role and Catholic academies are first and foremost for the poor and deprived, irrespective of faith tradition, would be one that stands in marked contrast to the current situation. Grace's promotion of the embryonic philosophy of Catholic education found in paragraph 58 of The Catholic School is allowing him to be prophetic in his convictions about the aims and content of Catholic education in the twenty-first century. In the light of this prophetic voice, the challenge now is to nurture this stance and develop in more robust terms what it means to frame the philosophy of Catholic education around the option for the poor. There is thus a striking convergence between what Grace has been calling for over the past twenty-five years and what has come to the fore with the papacy of Pope Francis.

\section{Notes}

1 In this chapter, the focus will be on the 'philosophy of Catholic education', rather than the notion of a 'Catholic' philosophy of education. Whilst there are a number of theorists who employ this ambiguous phrase, such as D'Souza (2018), Hunt and Nuzzi (2004) and Carmody (2011), making the case for a separate version of a specifically Roman Catholic version of every discipline within the field of philosophical studies is fraught with conceptual and epistemological issues.

2 It is interesting to note that Grace has deliberately eschewed McLaughlin's pejorative description of this as 'Catholic edubabble', despite his long and close working relationship with him. Presumably this is because it sounds as if McLaughlin is being unhelpfully dismissive of educational theory. I have argued more recently in Whittle (2021) that McLaughlin is actually seeking to safeguard the need for a properly worked-out theory of Catholic education, rather than relying on theological slogans and statements of piety. 
3 Grace's preference for the 1977 The Catholic School over Vatican II's Declaration is something I have challenged (most notably in Whittle, 2016). This is because Vatican II opted to produce a pastorally aware document that deliberately sought to tone down many aspects of Pius XI's encyclical. In contrast to subsequent documents by the Congregation for Catholic Education, the declaration has the advantage of saying less rather than more about Catholic education and schools. For a fuller defence of the superiority of Gravissimum Educationis over other post-conciliar education documents, see Whittle (2016).

4 It is important to appreciate the close relationship between Vatican II and the subsequent education documents published by the Congregation for Catholic Education. When Gravissimum Educationis was being considered by the then bishops at the council, they wanted to make a set of positive statements about education, both in the Catholic school and the university, rather than present a fully worked-out treatment of Catholic education. Moreover, the bishops clearly regarded these matters as important and in need of further treatment. One of the pivotal parts of Gravissimum Educationis is actually found in the introduction, which explains that there will be a special post-conciliar commission to develop and apply the fundamental principles identified in the declaration. Gravissimum Educationis is important both in itself and for bequeathing to the Church agenda a forum in which matters of Catholic education are to be further considered. Rather than being the definitive word on education from a Catholic perspective, Gravissimum Educationis is important because it is the beginning of an ongoing discussion about it. This discussion or dialogue has been unfolding in the decades after Vatican II in the various documents issued by the Congregation for Catholic Education, beginning with The Catholic School (1977). It is interesting to note that the 1977 document deliberately returned to the title that had been abandoned in the earlier draft versions because of the pressures of time.

5 Grace's distinctive development of the theme of spiritual capital is explored and analysed in Chapter 5 of this volume, by Casson ('Researching Spiritual Capital in Catholic Education: On the Need for Theoretical Frameworks and More Empirical Work').

6 The term 'confessional education' is a shorthand way of depicting what Hirst (1972) describes as a primitive or tribal education, where the primary goal of education and upbringing is to hand on the traditions, beliefs and wider cultural life of the tribe. Advocates of faith-based education systems can be characterised as sharing the same confessional desire of the tribal or primitive approach to education. A Catholic education which is aiming to hand on the faith traditions, beliefs and wider cultural life of Catholic Christianity could be described as confessional. In contrast, a nonconfessional approach is one which is not in its aims and practices seeking to be confessional or tribal in its approach to education.

7 This is 'A Theory of Catholic Education', Sean Whittle, 2014, London: Bloomsbury.

8 Throughout the twentieth century, the Natural Law political philosophy of Thomas Aquinas was regarded as authoritative within Catholic practice. Given this, it is hardly surprising that Divini Illus Magistri couches the discussion of parental rights in these terms.

9 At the primary level are to be found families, and these are the fundamental units of society. In the secondary supporting level there was the State. In essence, the State exists to help families fulfil their telos, which is the generation of children and their formation or education within families. There was a third level that came about when individuals joined the Church. This is a supernatural order in which there is a superiority to the natural order afforded by the State.

10 In a personal interview with Professor Grace, whilst writing this chapter, I sought to clarify his position on the status of parental rights in accessing Catholic schools. His answer was 'that parental rights are guaranteed not only by the Church but also by 
the United Nations Declaration on Human Rights. However, there is some evidence that the number of baptised Catholic students is reducing over time and a number of secondary schools have, in practice, a category of other students. A Governing Body which took seriously the Church's public commitments to the preferential option to the poor and those that are far from the faith might decide to use these principles in admitting other students from the local community. We need to be more inclusive of local communities than we are at present'. Grace's careful answer here, whilst not formally rejecting the Church's championing of parental rights alone, indicates how in the local context Governing Bodies could modify this official position and use the insights of Paragraph 58 to achieve the goal of Catholic schools being more inclusive of their local communities.

11 Here attention will be on the situation in England, given that this was the context of Grace's original research. However, Grace's stance on the philosophy of Catholic education would have serious practical implications for Catholic education internationally.

12 In this paragraph, I am suggesting that the thrust of Grace's stance would mean the priority for admission to a Catholic school ought to be around the principles of paragraph 58, rather than on those who have been baptised. In a situation where there are limited spaces available, it might well be that more affluent baptised Catholic children will not gain a place in a Catholic school. This is because socially disadvantaged children, who are perhaps also far from the faith, will be prioritised and be given admission.

13 The annual Catholic Education Service of England and Wales census data shows how, over many years, for increasing proportions of the Catholic community, choosing a Catholic school is no longer the default position. Overall, the data for 2019 shows that $68 \%$ of children at Catholic schools came from Catholic families. However, there are more than enough baptised children in the UK to fill all the spaces in Catholic schools; it is just that these families are choosing nonCatholic schools to educate their children. The cause of this is largely rooted in the sociological changes that have occurred among the Catholic community in Britain. The drift towards the adoption of middle-class values and attitudes, which the Catholic sociologist Michael Hornsby-Smith drew attention to in 1978 has continued apace (see Hornsby-Smith, 1999). Thus, it would appear that there are fewer poorer and socially disadvantaged Catholic families in England, and this would indicate that there ought to be fewer of these children at Catholic schools.

14 In the personal interview (see endnote 10), I asked Professor Grace about his stance on non-confessional Catholic schools. His answer was that he had been strongly influenced by the counter-argument to non-confessional Catholic schools written by Brendan Carmody SJ in ISCE (2017). Grace is convinced that postVatican II Catholic schools have moved from an indoctrinatory pedagogy to a dialogic pedagogy which respects the integrity of the student. As Carmody says 'the Catholic church sees its Catholic schools as confession but at the same time truly educative' (see The Catholic School, 1977). As paragraph 31 puts it, 'Catholic schools must develop people who are responsible and inter-directed, capable of choosing freely in conformity of their conscience'. Although Grace's answer is a rejection of non-confessional Catholic education, this does not detract from my concluding observation that his stance sounds very similar to the position I have argued for (Whittle, 2014a, 2014b) and described as non-confessional Catholic education.

15 For a fuller discussion of the issues surrounding academies and Catholic education, see Buck (2019) and Whittle (2020). 


\section{References}

Buck, M. (2019). Renewing the Church-State Partnership for Education. Oxford: Peter Lang.

Carmody, B. (2011). Towards a Contemporary Catholic Philosophy of Education, in International Studies in Catholic Education, 3:2, pp. 106-119.

Carmody, B. (2017). The Catholic School: Non-confessional?, in International Studies in Catholic Education, 9:2, pp. 162-175.

Carr, D., Haldane, J., McLaughlin, T. and Pring, R. (1995). Return to the Crossroads: Maritain Fifty Years On, in British Journal of Educational Studies, 43:2, pp. 162-178.

Congregation for Catholic Education. (1977). The Catholic School. London: Catholic Truth Society.

D'Souza, M. (2018). Further Reflections on a Catholic Philosophy of Education, in International Studies in Catholic Education, 10:1, pp. 2-14.

Elias, J. (1999). Whatever Happened to the Catholic Philosophy of Education?, in Religious Education, 94:1, pp. 92-110.

Grace, G. (2002). Catholic Schools: Missions, Markets and Morality. London: Routledge.

Grace, G. \& Lydon, J. (2020). Editorial, in International Studies in Catholic Education, 12:2, p. 129.

Gravissimum Educationis, in Abbott, W. (Ed.) (1966). The Documents of Vatican II. New York: Herder and Herder.

Hirst, P. (1972). Christian Education: A Contradiction in Terms, in Learning for Living, 11: 4, pp. 6-11.

Hornsby-Smith, M. (1999). Catholics in England 1950-2000: Historical and Sociological Perspectives. London: Cassell.

Hunt, T. \& Nuzzi, R. (Eds.) (2004). Handbook of Research on Catholic Education. New York: Greenwood Press.

Kelty, B. (1999). Towards a Theology of Catholic Education, in Religious Education, $94: 1$, pp. 6-23.

Pius XI, (1929). Divini Illus Magastri [On Christian Education of the Youth]. Papal Encyclical available at Vatican official website: Online at www.vatican/va.

Pring, R. (2017). The Future of Publicly Funded Schools. London: Routledge.

McLaughlin, T. H. (1996). The Distinctiveness of Catholic Education, in McLaughlin, T. H., O'Keefe, J. M. \& O'Keefe, B. (Eds). The Contemporary Catholic School: Context, Identity and Diversity. London: Falmer Press.

Wadman, D. (2015). Book Review of A Theory of Catholic Education, in International Studies in Catholic Education, 7:2, pp. 247-250.

Walsh, P. (2018). From Philosophy to Theology of Catholic Education, with Bernard Lonergan and Karl Rahner, in International Studies in Catholic Education, 10:2, pp. 132-155.

Whittle, S. (2014a). Towards a Contemporary Philosophy of Catholic Education: Moving the Debate Forward, in International Studies in Catholic Education, 6:1, pp. 46-59.

Whittle, S. (2014b). A Theory of Catholic Education. London: Bloomsbury.

Whittle, S. (Ed.) (2016). Vatican II and New Thinking about Catholic Education. London: Routledge.

Whittle, S. (Ed.) (2020). Conference Report from the First National Conference on Academisation. Whitehaven: Networking Education Trust Ltd.

Whittle, S. (Ed.) (2021). Irish and British Reflections on Catholic Education: Foundations, Identity, Leadership Issues and Religious Education in Catholic Schools. Singapore: Springer. 